\title{
Zone zero hybrid arch exclusion versus open total arch replacement
}

\author{
Ourania Preventza ${ }^{1,2}$, Corinne W. Tan ${ }^{2}$, Vicente Orozco-Sevilla ${ }^{2}$, Caleb J. Euhus ${ }^{2}$, Joseph S. Coselli ${ }^{1,2}$ \\ ${ }^{1}$ Department of Cardiovascular Surgery, Texas Heart Institute, Houston, TX, USA; ${ }^{2}$ Division of Cardiothoracic Surgery, Baylor College of Medicine, \\ Houston, TX, USA \\ Correspondence to: Ourania Preventza. Division of Cardiothoracic Surgery, Baylor College of Medicine, Houston, TX, USA; Department of \\ Cardiovascular Surgery, Texas Heart Institute, 6770 Bertner Avenue, Houston, TX 77030, USA. Email: opsmile01@aol.com.
}

\begin{abstract}
Open total aortic arch replacement is one of the most technically demanding operations in cardiothoracic surgery, requiring operator expertise and intraoperative and postoperative teamwork. Despite current advancements in the field of open aortic surgery with regard to intraoperative brain protection and postoperative care, the morbidity and mortality associated with open total arch operations varies. Endovascular and hybrid procedures involving the use of zone 0 as a landing zone allow fair comparison between open total arch and hybrid operations. Hybrid procedures involving all of the other landing zones [1-4] should not be compared with open total arch replacement, as the extent of the pathology is different.
\end{abstract}

Keywords: Aorta; thoracic; endovascular procedures; stents

Submitted Feb 22, 2018. Accepted for publication Mar 01, 2018.

doi: $10.21037 /$ acs.2018.04.03

View this article at: http://dx.doi.org/10.21037/acs.2018.04.03

\section{Introduction}

Because of their complexity, open total arch operations are limited to specialized aortic centers. In a recent large $(\mathrm{N}=3,265)$ retrospective study of open total arch replacement cases in the $\mathrm{ARCH}$ international aortic database, in-hospital mortality at specialized centers was more than $10 \%$, and the permanent neurologic deficit rate was more than $6.7 \%$ (1). In an effort to minimize the morbidity and mortality associated with these procedures, various catheter-based repair techniques called hybrid procedures have been developed to perform arch replacement by using commercially available endovascular technology or custom-made devices.

\section{Open total arch replacement}

Cooley and colleagues in 1955 reported the first aortic arch replacement (2), and Griepp and colleagues in 1975 introduced the application of hypothermia in aortic surgery by describing four cases of arch replacement involving hypothermic cardiac arrest (3). Newer open techniques and adjuncts have been developed to facilitate the conduct of the operation and to decrease associated morbidity and mortality (4-10). Our technique has evolved over the years with regards to brain protection, target temperature, cannulation strategy and cerebral perfusion. The following are some of the technical aspects of the open approach.

Depending on the individual case, different cannulation sites for cardiopulmonary bypass (CPB) have been used, such as the right axillary, innominate, right common carotid, and femoral arteries, usually either through a Dacron graft or by direct aortic cannulation for arterial inflow. Our most recent cannulation strategy has just been published (11). In cases of redo sternotomy with proximity of the ascending aorta and aortic arch to the sternum, right axillary artery cannulation with a side graft is our first choice. The target nasopharyngeal temperature is approximately 21 to $25^{\circ} \mathrm{C}$, and the near-infrared spectroscopy signals are monitored during the procedure. The different reconstruction techniques include island patch configuration with two or all three head vessels implanted and the Y-graft aortic arch repair with a prefabricated or custom-made bifurcated 
$(\mathrm{Y})$, trifurcated (double-Y), or single graft (Vascutek Ltd., a subsidiary of Terumo Corporation, Renfrewshire, Scotland), or a combination of these techniques.

We perform the elephant trunk (ET) procedure if the extent of aortic pathology warrants it. We use the side arm of the skirted ET Gelweave graft (Vascutek Ltd., Ann Arbor, Michigan, USA) for the purpose of maintaining full flow and perfusing the lower body distally during the aortic reconstruction after the distal anastomosis is completed. The length of the ET is approximately $8 \mathrm{~cm}$ and is limited to no more than $10 \mathrm{~cm}$ in an effort to prevent spinal cord ischemia. Even in cases when we use the frozen elephant trunk technique (FET), we do not cover more than $10-15 \mathrm{~cm}$ of the descending thoracic aorta, which others also have recommended to avoid spinal cord injury.

Regardless of the repair, antegrade cerebral perfusion (ACP) is our current and sole choice for cerebral perfusion during circulatory arrest. In all total arch operations, ACP is administered bilaterally via the right and left common carotid artery (LCCA) at a flow rate of $10 \mathrm{~mL} / \mathrm{kg} / \mathrm{min}$. In cases where the regional cerebral oxygen saturation reading from near-infrared spectroscopy decreases to less than $10 \%$ of the patient's baseline measurement, we increase the flow to $13 \mathrm{~mL} / \mathrm{kg} / \mathrm{min}$. Bilateral ACP is easily administered via a 9F Pruitt balloon-tip catheter inserted into the branches of the $\mathrm{Y}$ graft or, in cases of island arch repair, directly into the LCCA (LeMaitre Vascular, Burlington, Massachusetts, USA). The hybrid type III approach (12) is an open total arch operation used to treat the entire "mega-aorta" in one or two stages; the endovascular repair is performed on the descending thoracic aorta, and the "stented" landing zone facilitates the subsequent endovascular operations in the second stage $(13,14)$. Type III arch repair, although it is described as "hybrid arch repair", should not be included and mixed with the hybrid techniques involving zone 0 , because the patients and the stented area are different. As others have advocated (15), we limit the use of single-stage repair because of the associated risk of spinal cord ischemia. A specific device designed for this approach has been embraced widely in Europe; it involves the use of the Thoraflex hybrid prosthesis (Vascutek Ltd., Inchinnan, Glasgow, UK) (16) and the E-vita open stent-graft (JOTEC GmbH, Hechingen, Germany) (17). A national clinical trial of the Thoraflex hybrid prosthesis is currently underway in the United States (https://clinicaltrials.gov/ ct2/show/NCT02724072).

\section{Zone 0 landing zone and hybrid arch exclusion}

Nikolay Volodos' team performed the first hybrid aortic arch repair in 1991 (18); in 2013, Volodos reported that the patient was still alive and the stent graft was stable (19). Since then, great strides have been made in endovascular technology for treating aortic pathology. A totally endovascular approach is being developed that uses custom-made devices (20), which raises the question of device durability. When we discuss hybrid arch operations that are comparable to open total arch repair, the hybrid procedure should involve debranching the supra-aortic arch vessels: if not all of them, then at least the innominate artery, the LCCA, or both $(12,21,22)$. This approach avoids hypothermic circulatory arrest, CPB and aortic crossclamping. In hybrid type II arch repair, CPB is required, the ascending aorta is replaced with a Dacron graft and the Dacron graft in the ascending aorta is considered zone 0 . The hybrid procedure can be performed via median sternotomy or left thoracotomy, using the descending thoracic aorta for arterial inflow, if the median sternotomy is prohibitive (22). A series of extra-anatomic bypasses with arterial inflow to the iliac arteries have also been reported (23). The different landing zones have been described (24) as follows: zone 0 is in the ascending aorta, proximal to the brachiocephalic artery; zone 1 covers the aortic arch between the brachiocephalic artery and the LCCA; zone 2 covers the part of the arch between the LCCA and the left subclavian artery (SCA); zone 3 covers the proximal descending thoracic aorta distal to the left SCA; and zone 4 covers the mid-descending thoracic aorta.

Patel and colleagues $(25,26)$, in an analysis of 721 cases performed over 17 years at the University of Michigan, echo concerns from the Stanford group, that the majority of patients with proximal disease have aneurysm of the root and proximal ascending aorta with a "complex anatomy of the sinuses, sinotubular junction (STJ) and coronary ostia", making zone 0 hybrid debranching procedures challenging. In the classic zone 0 hybrid debranching procedure, classification described by Bavaria and colleagues (27), type IA involves the end-to-side anastomosis of a 4-branched graft to the ascending aorta, which is usually performed off bypass with a side-biting clamp on the ascending aorta. In contrast, type IB is done when there is limited amount of aorta between the STJ and the ascending aorta; full $\mathrm{CPB}$ and cross-clamping are required. The type II aortic arch repair is done when the native proximal aorta is unsuitable for grafting. This operation requires constructing the 


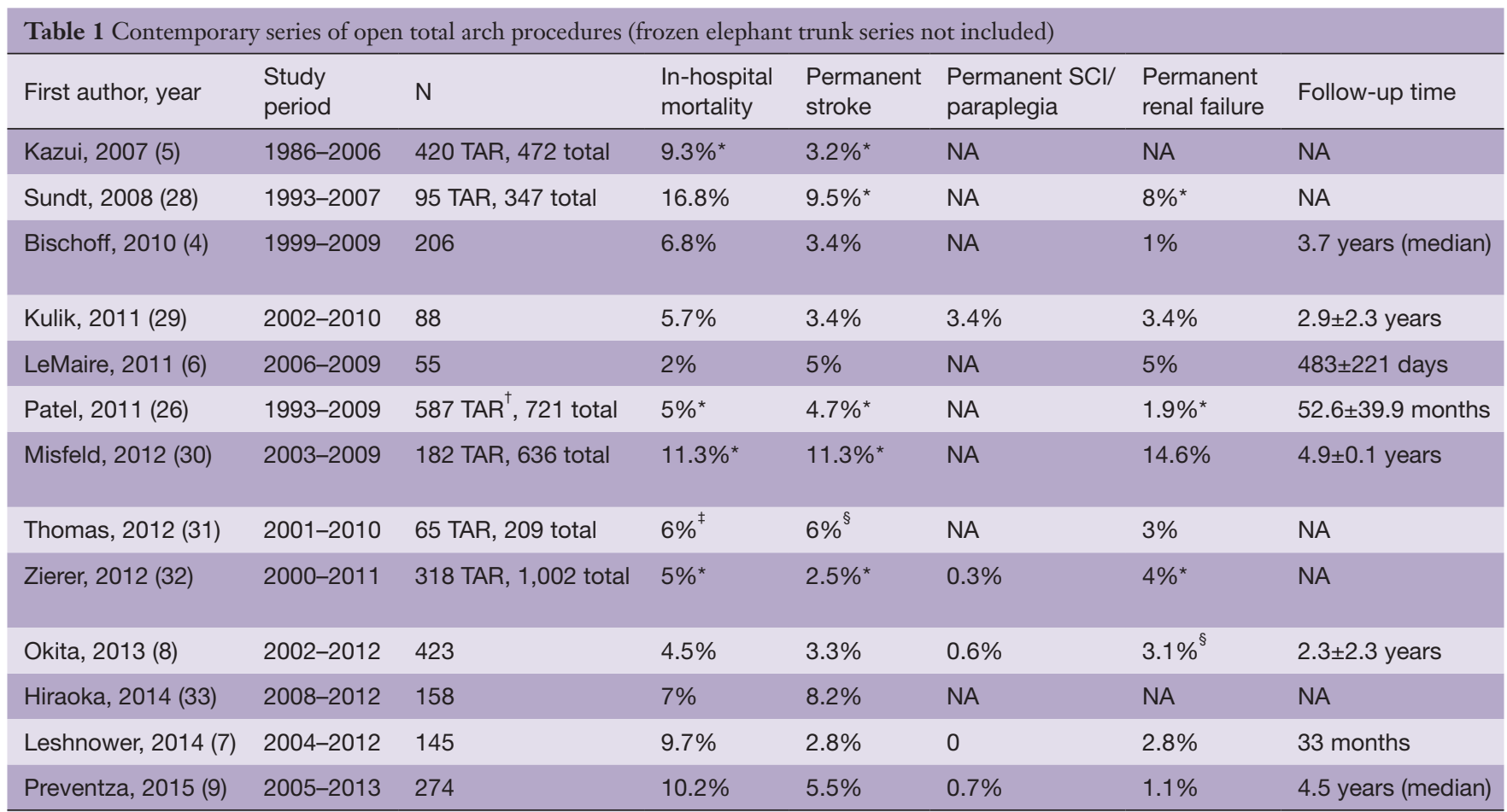

All Ns and percentages refer to total arch replacement patients only unless otherwise specified. Follow-up times are reported as means unless otherwise noted. *, refers to the entire cohort and not only the total arch replacement patients; ${ }^{\dagger}$, it is unclear how many of these procedures were total arch replacements. We infer that 587 of them were because they involved bypass to the innominate ( $n=296)$, left common carotid $(n=216)$, or subclavian artery $(n=75) ;{ }^{\ddagger}$, the in-hospital mortality rate was $5.5 \%$ for patients who underwent elective procedures and $10 \%$ for those who underwent emergency procedures; ${ }^{\S}$, not specified as temporary or permanent. NA, not available in published article; SCI, spinal cord injury; TAR, total arch replacement.

landing site, zone 0 , with a Dacron graft in the ascending aorta. The type III "hybrid" operation, as mentioned previously, is really an open total arch procedure in which the descending thoracic aorta is the stented segment.

Our hybrid approach involves median sternotomy and mobilizing the brachiocephalic vessels. Near-infrared spectroscopy is used during the supra-aortic vessel debranching, and the systemic mean aortic pressure is kept at 80 to $100 \mathrm{mmHg}$ during the head-vessel reconstruction. This reconstruction involves the use of a prefabricated $\mathrm{Y}$ graft (Vascutek) or a custom-made version prepared at the operating table. We begin the reconstruction by attaching the main body of the graft to the right anterolateral aspect of the ascending aorta. During this anastomosis, we keep the mean arterial pressure (MAP) low $(50-60 \mathrm{mmHg})$. The head-vessel debranching is performed distally to proximally by revascularizing the left SCA first (end-to-end anastomosis) and then the LCCA and innominate artery. During these anastomoses, the MAP is kept between 80 and $100 \mathrm{mmHg}$. If the left SCA is not accessible through the median sternotomy, a left carotid-to-subclavian bypass is done via a left supraclavicular incision during the same operation or a subsequent one. If the left vertebral artery originates from the arch, it is directly reattached to the side of the $\mathrm{Y}$ graft, the LCCA, or the left SCA. The endovascular exclusion of the arch is performed by delivering a stent antegrade or retrograde, according to the surgeon's preference and the quality and size of the iliofemoral vessels. If the ascending aorta is more than 4 to $4.5 \mathrm{~cm}$ in diameter and we believe that the patient can tolerate $\mathrm{CPB}$, we tend to replace the ascending aorta under $\mathrm{CPB}$ to prevent ascending aortic dissection. When more than $15 \mathrm{~cm}$ of the descending aorta is covered, a cerebrospinal fluid (CSF) catheter is inserted, and CSF is drained intraoperatively and postoperatively. In addition, we protect the spinal cord by increasing the MAP to 90 to $100 \mathrm{~mm} \mathrm{Hg}$ after stent deployment.

\section{Contemporary results}

Tables 1,2 show open total arch replacement results from 


\begin{tabular}{|c|c|c|c|c|c|c|c|c|c|}
\hline $\begin{array}{l}\text { First } \\
\text { author, } \\
\text { year }\end{array}$ & $\begin{array}{l}\text { Study } \\
\text { period }\end{array}$ & $\begin{array}{l}\text { No. zone } 0 \text { hybrid/ } \\
\text { debranching } \\
\text { procedures }\end{array}$ & $\begin{array}{l}\text { In-hospital } \\
\text { mortality }\end{array}$ & $\begin{array}{l}\text { Permanent } \\
\text { stroke }\end{array}$ & $\begin{array}{l}\text { Permanent } \\
\text { SCl/ } \\
\text { paraplegia }\end{array}$ & $\begin{array}{l}\text { Permanent } \\
\text { renal } \\
\text { failure }\end{array}$ & $\begin{array}{l}\text { Follow-up } \\
\text { time }\end{array}$ & RAAD & Endoleak \\
\hline $\begin{array}{l}\text { Gottardi, } \\
2008(34)\end{array}$ & $\begin{array}{l}1996- \\
2007\end{array}$ & $\begin{array}{l}13 \text { zone } 0,73 \text { all } \\
\text { zones }\end{array}$ & $23.1 \%$ & 0 & NA & NA & 37 months & NA & $\begin{array}{l}24.6 \% \text { early, } \\
13.6 \% \text { late }\end{array}$ \\
\hline $\begin{array}{l}\text { Weigang, } \\
2009 \text { (35) }\end{array}$ & NA & 26 zone 0 & $15.4 \%$ & 0 & 0 & NA & NA & NA & $3.8 \%$ \\
\hline $\begin{array}{l}\text { Geisbusch, } \\
2011(36)\end{array}$ & $\begin{array}{l}1997- \\
2009\end{array}$ & $\begin{array}{l}15 \text { zone } 0,47 \text { all } \\
\text { zones }\end{array}$ & $27 \%$ & 0 & 0 & $13.3 \%$ & 21.4 months & $6.7 \%$ & 0 \\
\hline $\begin{array}{l}\text { Czerny, } \\
2012 \text { (37) }\end{array}$ & $\begin{array}{l}2003- \\
2011\end{array}$ & $\begin{array}{l}66 \text { zone } 0 \text { ( } 5 \\
\text { centers) }\end{array}$ & $9 \%$ & $5 \%$ & $3 \%$ & NA & 25 months & $7.6 \%$ & $\begin{array}{l}22.6 \% \text { early, } \\
9.1 \% \text { late }\end{array}$ \\
\hline $\begin{array}{l}\text { Ferrero, } \\
2012 \text { (38) }\end{array}$ & $\begin{array}{l}2005- \\
2010\end{array}$ & $\begin{array}{l}11 \text { zone } 0,27 \text { all } \\
\text { zones }\end{array}$ & $9.1 \%$ & 0 & 0 & NA & $\begin{array}{l}11.8 \pm 9.7 \\
\text { months }\end{array}$ & NA & $3.7 \%$ late* $^{*}$ \\
\hline $\begin{array}{l}\text { Melissano, } \\
2012 \text { (39) }\end{array}$ & $\begin{array}{l}1999- \\
2011\end{array}$ & $\begin{array}{l}32 \text { zone } 0,143 \text { all } \\
\text { zones }\end{array}$ & $9.4 \%$ & $9.4 \%^{\dagger}$ & 0 & 0 & 5 years & NA & $\begin{array}{l}6.2 \% \text { early, } \\
3.1 \% \text { late }\end{array}$ \\
\hline $\begin{array}{l}\text { Vallejo, } \\
2012(23)\end{array}$ & $\begin{array}{l}2002- \\
2012\end{array}$ & $\begin{array}{l}27 \text { zone } 0,38 \text { all } \\
\text { zones }\end{array}$ & $29.6 \%$ & $7.4 \%^{\dagger}$ & $3.7 \%$ & $7.4 \%$ & 28.1 months & $3.7 \%$ & $\begin{array}{l}3.7 \% \text { early, } \\
7.4 \% \text { late }\end{array}$ \\
\hline $\begin{array}{l}\text { Andersen, } \\
2013 \text { (40) }\end{array}$ & $\begin{array}{l}2005- \\
2012\end{array}$ & $\begin{array}{l}48 \text { zone } 0,87 \text { all } \\
\text { zones }\end{array}$ & $20.8 \%$ & $4.2 \%^{\dagger}$ & 0 & $4.2 \%$ & $\begin{array}{l}28.4 \pm 21.5 \\
\text { months }\end{array}$ & $11.1 \%^{\ddagger}$ & $17 \%^{\S}$ \\
\hline $\begin{array}{l}\text { Bavaria, } \\
2013 \text { (12) }\end{array}$ & $\begin{array}{l}2005- \\
2012\end{array}$ & $\begin{array}{l}36 \text { zone } 0,47 \text { all } \\
\text { zones }\end{array}$ & $8 \%$ & $8 \%^{\dagger}$ & $6 \%$ & $3 \%$ & $\begin{array}{l}30 \pm 21 \\
\text { months }\end{array}$ & $2.8 \%$ & 0 \\
\hline $\begin{array}{l}\text { Cochennec, } \\
2013(41)\end{array}$ & $\begin{array}{l}2004- \\
2011\end{array}$ & $\begin{array}{l}7 \text { zone } 0,17 \text { all } \\
\text { zones }\end{array}$ & $14 \%$ & $14 \%$ & 0 & NA & 13 months & $14.3 \%$ & $28.6 \%$ \\
\hline $\begin{array}{l}\text { Kent, } \\
2014 \text { (42) }\end{array}$ & $\begin{array}{l}2007- \\
2012\end{array}$ & $\begin{array}{l}20 \text { zone } 0 \text { ( } 2 \\
\text { centers) }\end{array}$ & $5 \%$ & $5 \%$ & 0 & 0 & $\begin{array}{l}18.5 \pm 15.3 \\
\text { months }\end{array}$ & NA & $15 \%$ early \\
\hline $\begin{array}{l}\text { Preventza, } \\
2015 \text { (9) }\end{array}$ & $\begin{array}{l}2005- \\
2013\end{array}$ & 45 zone 0 & $11.1 \%$ & $8.9 \%$ & 0 & 0 & 4.5 years & 0 & NA \\
\hline $\begin{array}{l}\text { Faure, } \\
2016 \text { (43) }\end{array}$ & $\begin{array}{l}2005- \\
2015\end{array}$ & $\begin{array}{l}11 \text { zone } 0,33 \text { all } \\
\text { zones }\end{array}$ & $9 \%$ & $18 \%^{\dagger}$ & $9 \%^{\dagger}$ & $\begin{array}{l}\text { NA for } \\
\text { zone } 0\end{array}$ & 24.3 months & 0 & $9 \%$ late \\
\hline $\begin{array}{l}\mathrm{He}, \\
2016 \text { (44) }\end{array}$ & $\begin{array}{l}2012- \\
2015\end{array}$ & $\begin{array}{l}16 \text { zone } 0,43 \text { all } \\
\text { zones }\end{array}$ & $6.25 \%$ & 0 & 0 & $6.25 \%{ }^{*}$ & 15 months & 0 & $\begin{array}{l}2.3 \% \text { early*, } \\
4.8 \% \text { late* }\end{array}$ \\
\hline $\begin{array}{l}\text { Aalaei- } \\
\text { Andabili, } \\
2017 \text { (45) }\end{array}$ & $\begin{array}{l}2010- \\
2015\end{array}$ & 48 zone 0 & $17 \%$ & $6 \%^{\dagger}$ & $2 \%$ & $10.4 \%$ & 17 months & $N A^{\pi}$ & $5 \%$ late \\
\hline
\end{tabular}

All Ns and percentages refer only to patients who underwent zone 0 procedures unless otherwise specified. Follow-up times are reported as means unless otherwise noted. * ${ }^{*}$, refers to entire cohort (not just to patients who underwent zone 0 procedures); ${ }^{\dagger}$, not specified as permanent or temporary; ${ }^{\ddagger}$, percentage represents 3 out of 27 patients who were at risk because their landing zone was in the native ascending aorta; ${ }^{\S}$, not specified as early or late; ", 17.5 months is reported in the text, whereas the abstract says 18.5 months; ", type II repair only; not at risk for RAAD. NA, not available in published article; RAAD, retrograde ascending aortic dissection; SCl, spinal cord injury.

various well-known aortic centers and results on zone 0 procedures in which the stent graft is landed in the ascending aorta and debranching of the supra-aortic vessels has occurred. Although there are no randomized controlled trial data to support any particular approach for treating aortic arch pathology, a few comparative studies (Table 3) have examined the outcomes of traditional arch repair versus zone 0 hybrid repair. Benedetto and colleagues (52) identified four comparative observational studies of open total arch replacement versus hybrid thoracic endovascular aortic repair that included a total of 378 cases (269 open, 109 hybrid). Their pooled analysis did not show any 


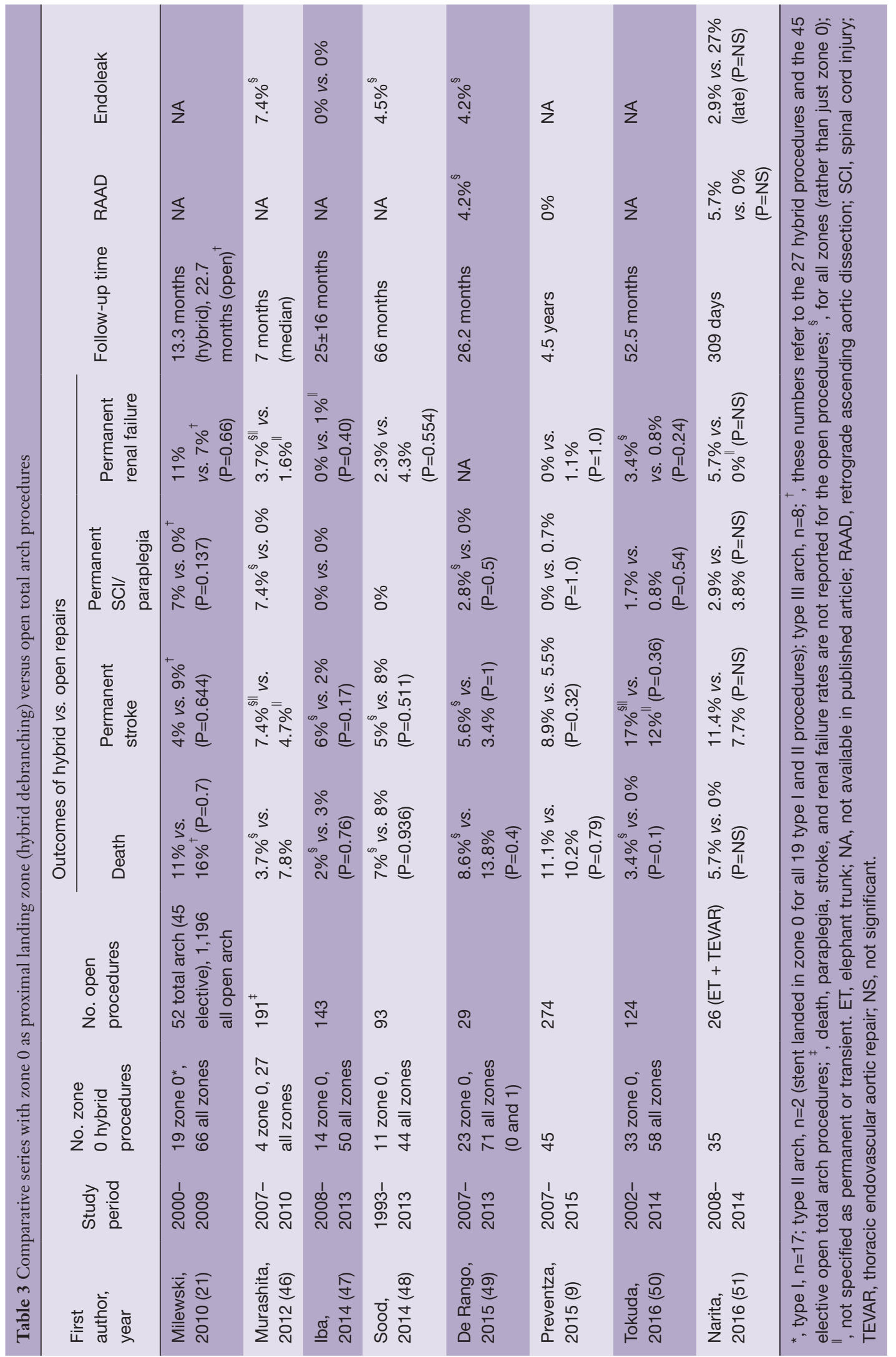


significant reduction in mortality in the hybrid group. Our study (9) echoes these findings: survival during the 4.5-year follow-up period was similar between the hybrid and traditional cohorts. The two propensity-matched subgroups did not differ with regard to survival $(85.7 \%$ for the hybrid and $69.6 \%$ for the traditional group, $\mathrm{P}=0.29$ ). Numerous studies in the literature are confusing, using the terms "hybrid" and "debranching" interchangeably and often not distinguishing among the different landing zones (Z0-Z3) and hybrid procedures (I, II, and III). Given the multiple partial and complete revascularization approaches and the heterogeneity of the patient population, it is challenging to compare apples to apples.

\section{Conclusions}

In the treatment of total aortic arch pathology, the traditional open repair remains the gold standard. The expansion of hybrid zone 0 repair promises a new treatment avenue for high-risk patients who may not be able to tolerate a prolonged standard open repair with $\mathrm{CPB}$ and circulatory arrest. However, definitive conclusions cannot yet be drawn about the superiority of one treatment versus the other. Rather, the choice of repair technique is influenced by patients' comorbidities and age. A better definition of the "high-risk patient" is required, and careful review of the literature is imperative.

\section{Acknowledgements}

Stephen N. Palmer, PhD, ELS, contributed to the editing of the manuscript.

\section{Footnote}

Conflicts of Interest: Dr. O Preventza is a consultant for W.L. Gore and Associates, is a former Medtronic consultant, and participates in clinical studies for Medtronic, Gore, and Vascutek Terumo. Dr. JS Coselli is a consultant for Vascutek Terumo, Gore, and Medtronic; receives royalties from Vascutek Terumo; and participates in trials for Vascutek Terumo, Gore, Medtronic, Bolton Medical, Abbott, and Edwards Lifesciences. The other authors have no conflicts of interest to declare.

\section{References}

1. Keeling WB, Tian DH, Leshnower BG, et al. Safety of moderate hypothermia with antegrade perfusion in total aortic arch replacement. Ann Thorac Surg 2018;105:54-61.

2. Cooley DA, Mahaffey DE, De Bakey ME. Total excision of the aortic arch for aneurysm. Surg Gynecol Obstet 1955;101:667-72.

3. Griepp RB, Stinson EB, Hollingsworth JF, et al. Prosthetic replacement of the aortic arch. J Thorac Cardiovasc Surg 1975;70:1051-63.

4. Bischoff MS, Brenner RM, Scheumann J, et al. Longterm outcome after aortic arch replacement with a trifurcated graft. J Thorac Cardiovasc Surg 2010;140:S716; discussion S86-91.

5. Kazui T, Yamashita K, Washiyama N, et al. Aortic arch replacement using selective cerebral perfusion. Ann Thorac Surg 2007;83:S796-8; discussion S824-31.

6. LeMaire SA, Price MD, Parenti JL, et al. Early outcomes after aortic arch replacement by using the Y-graft technique. Ann Thorac Surg 2011;91:700-7; discussion 707-8.

7. Leshnower BG, Kilgo PD, Chen EP. Total arch replacement using moderate hypothermic circulatory arrest and unilateral selective antegrade cerebral perfusion. J Thorac Cardiovasc Surg 2014;147:1488-92.

8. Okita Y, Okada K, Omura A, et al. Total arch replacement using antegrade cerebral perfusion. J Thorac Cardiovasc Surg 2013;145:S63-71.

9. Preventza O, Garcia A, Cooley DA, et al. Total aortic arch replacement: A comparative study of zone 0 hybrid arch exclusion versus traditional open repair. J Thorac Cardiovasc Surg 2015;150:1591-8; discussion 1598-600.

10. Preventza O, Garcia A, Cooley DA, et al. Reoperations on the total aortic arch in 119 patients: short- and mid-term outcomes, focusing on composite adverse outcomes and survival analysis. J Thorac Cardiovasc Surg 2014;148:2967-72.

11. Preventza O, Price MD, Spiliotopoulos K, et al. In elective arch surgery with circulatory arrest, does the arterial cannulation site really matter? A propensity score analysis of right axillary and innominate artery cannulation. J Thorac Cardiovasc Surg 2018;155:1953-60.e4.

12. Bavaria J, Vallabhajosyula P, Moeller P, et al. Hybrid approaches in the treatment of aortic arch aneurysms: postoperative and midterm outcomes. J Thorac Cardiovasc Surg 2013;145:S85-90.

13. Preventza O, Al-Najjar R, LeMaire SA, et al. Total arch replacement with frozen elephant trunk technique. Ann Cardiothorac Surg 2013;2:649-52.

14. Preventza O, Coselli JS, Mayor J, et al. The stent is 
not to blame: lessons learned with a simplified US version of the frozen elephant trunk. Ann Thorac Surg 2017;104:1456-63.

15. Roselli EE. Trade in the hammer for a power driverperspectives on the frozen elephant trunk repair for aortic arch disease. Ann Cardiothorac Surg 2013;2:633-9.

16. Shrestha M, Kaufeld T, Beckmann E, et al. Total aortic arch replacement with a novel 4-branched frozen elephant trunk prosthesis: Single-center results of the first 100 patients. J Thorac Cardiovasc Surg 2016;152:148-59.e1.

17. Leontyev S, Tsagakis K, Pacini D, et al. Impact of clinical factors and surgical techniques on early outcome of patients treated with frozen elephant trunk technique by using EVITA open stent-graft: results of a multicentre study. Eur J Cardiothorac Surg 2016;49:660-6.

18. Volodos NL, Karpovich IP, Troyan VI, et al. Clinical experience of the use of self-fixing synthetic prostheses for remote endoprosthetics of the thoracic and the abdominal aorta and iliac arteries through the femoral artery and as intraoperative endoprosthesis for aorta reconstruction. Vasa Suppl 1991;33:93-5.

19. Volodos NL. Historical perspective: The first steps in endovascular aortic repair: how it all began. J Endovasc Ther 2013;20 Suppl 1:I3-23.

20. Spear R, Clough RE, Fabre D, et al. Total endovascular treatment of aortic arch using an arch endograft with 3 inner branches. J Endovasc Ther 2017;24:534-8.

21. Milewski RK, Szeto WY, Pochettino A, et al. Have hybrid procedures replaced open aortic arch reconstruction in high-risk patients? A comparative study of elective open arch debranching with endovascular stent graft placement and conventional elective open total and distal aortic arch reconstruction. J Thorac Cardiovasc Surg 2010;140:590-7.

22. Preventza O, Bakaeen FG, Cervera RD, et al. Deployment of proximal thoracic endograft in zone 0 of the ascending aorta: treatment options and early outcomes for aortic arch aneurysms in a high-risk population. Eur J Cardiothorac Surg 2013;44:446-52; discussion 452-3.

23. Vallejo N, Rodriguez-Lopez JA, Heidari P, et al. Hybrid repair of thoracic aortic lesions for zone 0 and 1 in highrisk patients. J Vasc Surg 2012;55:318-25.

24. Ishimaru S. Endografting of the aortic arch. J Endovasc Ther 2004;11 Suppl 2:II62-71.

25. Fazel SS, Mallidi HR, Lee RS, et al. The aortopathy of bicuspid aortic valve disease has distinctive patterns and usually involves the transverse aortic arch. J Thorac Cardiovasc Surg 2008;135:901-7, 907.e1-2.

26. Patel HJ, Nguyen C, Diener AC, et al. Open arch reconstruction in the endovascular era: analysis of 721 patients over 17 years. J Thorac Cardiovasc Surg 2011;141:1417-23.

27. Bavaria J, Milewski RK, Baker J, et al. Classic hybrid evolving approach to distal arch aneurysms: toward the zone zero solution. J Thorac Cardiovasc Surg 2010;140:S77-80; discussion S86-91.

28. Sundt TM 3rd, Orszulak TA, Cook DJ, et al. Improving results of open arch replacement. Ann Thorac Surg 2008;86:787-96; discussion 787-96.

29. Kulik A, Castner CF, Kouchoukos NT. Outcomes after total aortic arch replacement with right axillary artery cannulation and a presewn multibranched graft. Ann Thorac Surg 2011;92:889-97.

30. Misfeld M, Leontyev S, Borger MA, et al. What is the best strategy for brain protection in patients undergoing aortic arch surgery? A single center experience of 636 patients. Ann Thorac Surg 2012;93:1502-8.

31. Thomas M, Li Z, Cook DJ, et al. Contemporary results of open aortic arch surgery. J Thorac Cardiovasc Surg 2012;144:838-44.

32. Zierer A, El-Sayed Ahmad A, Papadopoulos N, et al. Selective antegrade cerebral perfusion and mild $\left(28^{\circ} \mathrm{C}-30^{\circ} \mathrm{C}\right)$ systemic hypothermic circulatory arrest for aortic arch replacement: results from 1002 patients. J Thorac Cardiovasc Surg 2012;144:1042-49.

33. Hiraoka A, Chikazawa G, Totsugawa T, et al. Open total aortic arch reconstruction for patients with advanced age in the era of endovascular repair. J Thorac Cardiovasc Surg 2014;148:77-82.

34. Gottardi R, Funovics M, Eggers N, et al. Supra-aortic transposition for combined vascular and endovascular repair of aortic arch pathology. Ann Thorac Surg 2008;86:1524-9.

35. Weigang E, Parker J, Czerny M, et al. Endovascular aortic arch repair after aortic arch de-branching. Ann Thorac Surg 2009;87:603-7.

36. Geisbüsch P, Kotelis D, Müller-Eschner M, et al. Complications after aortic arch hybrid repair. J Vasc Surg 2011;53:935-41.

37. Czerny M, Weigang E, Sodeck G, et al. Targeting landing zone 0 by total arch rerouting and TEVAR: midterm results of a transcontinental registry. Ann Thorac Surg 2012;94:84-9.

38. Ferrero E, Ferri M, Viazzo A, et al. Is total debranching a safe procedure for extensive aortic-arch disease? A single experience of 27 cases. Eur J Cardiothorac Surg 2012;41:177-82. 
39. Melissano G, Tshomba Y, Bertoglio L, et al. Analysis of stroke after TEVAR involving the aortic arch. Eur J Vasc Endovasc Surg 2012;43:269-75.

40. Andersen ND, Williams JB, Hanna JM, et al. Results with an algorithmic approach to hybrid repair of the aortic arch. J Vasc Surg 2013;57:655-67; discussion 666-7.

41. Cochennec F, Tresson P, Cross J, et al. Hybrid repair of aortic arch dissections. J Vasc Surg 2013;57:1560-7.

42. Kent WD, Appoo JJ, Bavaria JE, et al. Results of type II hybrid arch repair with zone 0 stent graft deployment for complex aortic arch pathology. J Thorac Cardiovasc Surg 2014;148:2951-5.

43. Faure EM, Canaud L, Marty-Ane C, et al. Hybrid aortic arch repair for dissecting aneurysm. J Thorac Cardiovasc Surg 2016;152:162-8.

44. He X, Liu W, Li Z, et al. Hybrid approach to management of complex aortic arch pathologies: a single-center experience in China. Ann Vasc Surg 2016;31:23-9.

45. Aalaei-Andabili SH, Scali S, Klodell C, et al. Outcomes of antegrade stent graft deployment during hybrid aortic arch repair. Ann Thorac Surg 2017;104:538-44.

46. Murashita T, Matsuda H, Domae K, et al. Less invasive surgical treatment for aortic arch aneurysms in highrisk patients: a comparative study of hybrid thoracic endovascular aortic repair and conventional total arch

Cite this article as: Preventza O, Tan CW, Orozco-Sevilla V, Euhus CJ, Coselli JS. Zone zero hybrid arch exclusion versus open total arch replacement. Ann Cardiothorac Surg 2018;7(3):372-379. doi: 10.21037/acs.2018.04.03 replacement. J Thorac Cardiovasc Surg 2012;143:1007-13.

47. Iba Y, Minatoya K, Matsuda H, et al. How should aortic arch aneurysms be treated in the endovascular aortic repair era? A risk-adjusted comparison between open and hybrid arch repair using propensity score-matching analysis. Eur J Cardiothorac Surg 2014;46:32-9.

48. Sood V, Patel HJ, Williams DM, et al. Open and endovascular repair of the nontraumatic isolated aortic arch aneurysm. J Vasc Surg 2014;60:57-63.

49. De Rango P, Ferrer C, Coscarella C, et al. Contemporary comparison of aortic arch repair by endovascular and open surgical reconstructions. J Vasc Surg 2015;61:339-46.

50. Tokuda Y, Oshima H, Narita Y, et al. Hybrid versus open repair of aortic arch aneurysms: comparison of postoperative and mid-term outcomes with a propensity score-matching analysis. Eur J Cardiothorac Surg 2016;49:149-56.

51. Narita H, Komori K, Usui A, et al. Postoperative outcomes of hybrid repair in the treatment of aortic arch aneurysms. Ann Vasc Surg 2016;34:55-61.

52. Benedetto U, Melina G, Angeloni E, et al. Current results of open total arch replacement versus hybrid thoracic endovascular aortic repair for aortic arch aneurysm: a meta-analysis of comparative studies. J Thorac Cardiovasc Surg 2013;145:305-6. 